\title{
Intoxicação espontânea por larvas de Perreyia flavipes (pergidae) em ovinose bovinos e intoxicação experimental em ovinos e coelhos*
}

\author{
DJEISON LUTIER RAYMUNDO
}

\author{
David Driemeier (Orientador - UFRGS)
}

Banca: Aldo Gava (UDESC), Ana Lúcia Schild (UFPel), Claudio Severo Lombardo de Barros (UFSM)

Entre os meses de junho e agosto de 2006 dois surtos de intoxicação pelas larvas de $P$. flavipes ocorreram, um em ovinos (surto 1) e outro em bovinos (surto 2). O surto nos ovinos ocorreu nos meses de junho e julho, no município de Encruzilhada do Sul/RS, e morreram 25 ovinos de um rebanho de 175 ovinos e 11 bovinos. Os ovinos eram mantidos em uma área de 40 hectares de pasto nativo. O surto nos bovinos ocorreu no mês de agosto, no município de Sombrio/SC, e morreram 17 animais que estavam num lote de 77 bovinos, o rebanho total da propriedade era de 280 animais. O lote de bovinos estava em uma área de 90 hectares, onde dois animais morreram devido à ingestão das larvas de $P$. flavipes. O lote foi transferido para outra área, onde morreram mais 15 animais em um período de 5 dias. Seis ovinos do surto 1 e seis bovinos do surto 2 foram necropsiados. Grande quantidade de agrupamentos de larvas de $P$. flavipes foram encontradas no campo e no rúmen dos animais de ambos os surtos. Larvas de $P$. flavipes foram coletadas em ambos os surtos e foram armazenadas congeladas a $-20^{\circ} \mathrm{C}$. Larvas frescas e larvas congeladas foram administradas para 6 ovinos, por meio de uma seringa com a ponta cortada. A menor dose letal foi de $7,5 \mathrm{~g} / \mathrm{kg}$ em administração única. Animais que receberam doses sub-letais de $5 \mathrm{~g} / \mathrm{kg}$ e posteriormente doses letais de $10 \mathrm{~g} / \mathrm{kg}$ e $15 \mathrm{~g} / \mathrm{kg}$ em intervalos de 15 e 30 dias, mostraram menor sensibilidade à intoxicação, um animal não adoeceu e outro adoeceu apenas depois de receber uma dose de $15 \mathrm{~g} / \mathrm{kg}$. Os animais intoxicados experimentalmente mostraram sinais de doença cerca de 48 horas e morreram cerca de 54 horas após a intoxicação. O exame bioquímico, realizado em intervalos de 12 horas, revelou alterações apenas nos animais que adoeceram. Os níveis séricos de GGT apresentavam-se elevados depois de 24 horas da intoxicação e continuaram a se elevar até a morte; AST apresentou aumento significativo cerca de 30 horas após a dosificação e, posteriormente, decaindo até a morte; os níveis séricos de glicose sofreram queda próximo à morte dos animais. As lesões de necropsia, observadas nos casos espontâneos e experimentais, foram semelhantes e mais consistentes no fígado, que se apresentava com acentuação do padrão lobular e com áreas de coloração amarelada com petéquias subcapsulares. Foram observados também edemas cavitários, edema da parede da vesícula biliar, perirrenal e na região inicial do duodeno, pâncreas e abomaso. Além das hemorragias no fígado, havia hemorragias no tecido subcutâneo, coração, e mucosas e serosas da cavidade abdominal. O principal achado histopatológico era caracterizado por necrose coagulativa centrolobular ou massiva, associada à hemorragia e congestão centrolobular e degeneração e tumefação hepática na região periportal. Observou-se, ainda, depleção e necrose linfóide nos centros germinativos de linfonodos, nas placas de Peyer e na polpa branca do baço. A microscopia eletrônica demonstrou lesão hepática com hepatócitos necróticos, e dilatação dos espaços de Disse e endotélio vascular. Foi observada também intensa proliferação de retículo endoplasmático liso no animal que recebeu doses graduais das larvas. As larvas descongeladas e dessecadas a $100^{\circ} \mathrm{C}$, por 24 horas, foram administradas a um coelho e mostraramse tóxicas. Outros dois coelhos receberam frações sólidas e líquidas das larvas, respectivamente, e apenas o coelho que recebeu a fração sólida morreu.

Descritores: Perreyia flavipes, intoxicação por larvas, necrose hepática, ovinos e bovinos.

Apresentada: 26 fevereiro 2008

*Dissertação de Mestrado n. 491 (Especialidade: Patologia Animal). 69f. Programa de Pós-graduação em Ciências Veterinárias [www.ufrgs.br/ ppgcv], Faculdade de Veterinária, Universidade Federal do Rio Grande do Sul (UFRGS), Porto Alegre/RS. CORRESPONDÊNCIA: D.L. Raymundo [djraimundo@yahoo.com.br]. 


\title{
Spontaneous poisoning by larvae of Perreyia flavipes (pergidae) in sheep and cattle and experimental poisoning in sheep and rabbits**
}

\author{
DJEISON LUTIER RAYMUNDO
}

David Driemeier (Adviser - UFRGS)

Committee: Aldo Gava (UDESC), Ana Lúcia Schild (UFPel), Claudio Severo Lombardo de Barros (UFSM)

Between June and August 2006, two outbreaks of P. flavipes larvae poisoning were observed. In outbreak 1 occurred in a farm located at the county of Encruzilhada do Sul, Rio Grande do Sul State, Brazil, 25 out of 175 sheep were affected and died. Although there were 11 cattle in the same paddock, none of them was affected. Animals were kept in a 40 hectares paddock of native pastures. In outbreak 2, occurred in a farm located at county of Sombrio, Santa Catarina State, 11 out of 77 cattle were affected and died. In total, 6 sheep and 6 cattle from respective outbreaks were necropsied. High numbers of compact masses containing up to 150 larvae were scattered on the paddocks in which animals were grazing. Larvae were collected and frozen at $-20^{\circ} \mathrm{C}$. Perreyia flavipes larval body fragments and heads were found in the forestomach contents of all necropsied animals. Fresh and thawed larvae were administered to six sheep by a tip-cut plastic syringe. The lower single lethal dosis was $7,5 \mathrm{~g} / \mathrm{kg}$. Animals which received an initial sublethal doses of $5 \mathrm{~g} / \mathrm{kg}$ and subsequently were dosed with lethal 10 to $15 \mathrm{~g} / \mathrm{kg}$ at 15 and 30 days intervals showed lower susceptibility to the intoxication. Animals that were experimentally poisoned showed signs of disease about $48 \mathrm{~h}$ after dosing and died in approximately $54 \mathrm{~h}$. Biochemical tests performed at $12 \mathrm{~h}$ intervals showed changes only in diseased animals. Serum levels of GGT started being higher 24h after intoxication and kept enhancement until death. AST serum levels were significatively enhanced about $30 \mathrm{~h}$ after dosing and then, decreased to death. Glucose serum levels decreased close to the death. Necropsy lesions were similar in both, spontaneous and experimental cases and were most prominent in the livers, which had enhanced lobular pattern and yellowish areas with subcapsular pinpoint hemorrhages. Edema in body cavities, gallbladder wall, perirenal tissues, initial portion of duodenum, pancreas, and abomasum was also seen. Hemorrhages were also present in subcutaneous tissues, heart, and in mucosal and serosal membranes of the abdominal cavity. The principal histological finding was centrolobular to massive coagulative necrosis associated with centrolobular hemorrhage and congestion and periportal degeneration and tumefaction. There also were lymphoid depletion and necrosis in the germinative centres of lymph nodes, Peyer's patches, and white pulp of the spleen. Transmission electron microscopy showed necrotic hepatocytes and dilatation in the space of Disse and vascular endothelium. Severe proliferation of smooth endoplasmic reticulum was also seen in animal receiving more than one dosis of larvae. Thawed larvae were desiccated at $100^{\circ} \mathrm{C}$ for $24 \mathrm{~h}$ and administered to one rabbit that also became ill. Additional two rabbit were dosed with solid or liquid fractions of larvae and only which received the solid fraction died.

Key words: Perreyia flavipes, sawfly larval poisoning, liver necrosis, sheep and cattle.

Presented: 26 February 2008

**Master's Thesis \#491 (Field: Animal Pathology). 69p. Graduate Program in Veterinary Sciences [www.ufrgs.br/ppgcv], Faculdade de Veterinária, Universidade Federal do Rio Grande do Sul (UFRGS), Porto Alegre/Brazil. CORRESPONDENCE: D. L. Raymundo [djraimundo@yahoo.com.br]. 